\title{
The Degree of Applying of Standards of Total Quality Management in Jordanian Universities in the Light of the International Standards
}

\author{
Majd Fayez Sulieman Al-Adwan ${ }^{1}$ \\ ${ }^{1}$ Researcher, Amman, Jordan \\ Correspondence: Majd Fayez Sulieman Al-Adwan, Researcher, Amman, Jordan, Code 11934, Shafa-Badran, \\ Amman, Jordan. E-mail: majdaladwan@yahoo.com
}

Received: July 15, 2020

Accepted: August 20, 2020

Online Published: August 30, 2020

doi:10.5539/ijbm.v15n9p179

URL: https://doi.org/10.5539/ijbm.v15n9p179

\begin{abstract}
This study aimed to know the degree of applying standards of total quality management in the Jordanian universities in the light of the international standards. The study population included all the heads of academic departments in the Jordanian universities for the academic year (2015/ 2016). The study sample has been chosen from the study population $b$ using the stratified random method. To achieve the objectives study, the researcher developed the study tool that comprised the following domains: (vision, mission, objectives, operations management, continuous improvement, beneficiaries' satisfaction, evaluation), both the validity and reliability of the tool were verified. The researcher distributed the tool over the sample of the study and carried out the relative statistical processing. The results showed that the degree of applying the standards of total quality management in the Jordanian universities is medium, also it showed that there are no statistically significant differences at the $(0.05=\alpha)$ level attributed to (the gender, the specialization, and the years of experience). While as there are differences attributed to region variable, in favor the southern region. According to the results, the researcher recommended to hold training courses and field workshops in order to activate the standards of total quality management.
\end{abstract}

Keywords: total quality management, the Jordanian universities, the international standards

\section{General Framework}

\subsection{Introduction}

Science remains a major reason for the development and progress of nations and for keeping pace with developed countries, so we find the majority of countries resort to education as a primary source of development after seeing that small countries increased their per capita income clearly by following good quality and efficient educational systems , since achieving the goals at their lower levels are no longer been the desired goal, but rather reaching the highest levels of ambitious mastery has become the ambition that everyone is trying to achieve.

This is why interest has recently increased in comprehensive quality until it became the daily topic, in addition to many factors that had an active role in the increase in attention to quality, especially the quality of education (Al-Ghamdi, 2009). University education is witnessing great interest at different levels, in addition to constantly development for the better to cope with the needs of the individual and society and the characteristics of the scientific and technical age; Accordingly, university education is seen on the basis of the distinguished role it meets in the progress and development of societies through preparation of cadres and technical, scientific, cultural and professional human energies (Al-Tayiy and others, 2008).

It is expected that this interest will increase in the future due to the global complaint about the low levels of quality in education, so the application of quality management in higher education institutions is one of the main educational issues to universities in both developed and developing countries, in order to increase the effectiveness of those universities, and improving the quality of their education there (Shehata, 2012).

\subsection{The Problem of the Study}

There is a belief that educational institutions have recently become increasingly complex and unstable, as a result of the many challenges that these institutions face due to changes in the surrounding environment, so there is a need to develop and improve these institutions and achieve their quality. The approach to applying comprehensive quality management standards in the light of global standards in Jordanian universities is one of 
the modern approaches that seek to improve the efficiency and effectiveness of educational institutions, by increasing their ability to confront environmental changes and meet the requirements of their beneficiaries, in addition to constantly improving the quality of the programs offered to them, according to the study of (Bani Awad, 2013), despite the adoption of the Jordanian universities to the philosophy of comprehensive quality management, but there is a weakness in the application of this philosophy.

In addition to that there is a conviction in the social and academic circles in the Arab world that the university administration lacks a culture of applying comprehensive quality, and that the majority of Arab universities suffer from a lack of autonomy, the large number of regulations, systems and instructions, their ambiguity and their contradiction, and the multiplicity of levels or administrative and hierarchical links in writing reports and control (Majeed\& Ziyadat, 2008). And based on the above, to obtain a successful and effective educational learning environment by applying comprehensive quality management standards and working to improve and develop them continuously, we must rely on international standards, models and standards that have been tried in the developed world and that are inferred and guided as standards, principles and elements such as international organization specifications For international standards (ISO9001-2000), European quality standards and international quality models. The current problem of the study has emerged with the following main question: What is the degree of application of comprehensive quality management standards in Jordanian universities in the light of international standards?

\subsection{Study Questions}

This study sought to answer the following questions:

Q1: What is the degree of applying comprehensive quality management standards in the official Jordanian universities in light of Global standards from the viewpoint of academic heads of the department in it?

Q2: Are there statistically significant differences at the level of significance $(\mathrm{a}=0.05)$ in the degree of application of comprehensive quality management standards in official Jordanian universities in light of international standards from the viewpoint of academic department heads according to the variables (gender, years of experience, specialization and region)?

\subsection{Purpose of the Study}

The study aimed to reveal the degree of application of comprehensive quality management standards in the official Jordanian universities in the light of international standards from the viewpoint of academic department heads in them according to the variables (gender, years of experience, specialization, and region).

\subsection{The Importance of the Study}

The importance of conducting the current study lies in the need to seek the standards of comprehensive quality management that Jordanian universities have achieved, as it helps all administrative and academic personnel in the university field to improve the administrative and educational process in universities. Its importance also comes through handling a modern topic that is emerging in higher education and educational institutions In developed countries, it is the application of comprehensive quality management standards in light of global standards in University education institutions, in addition, their application is extremely important; In order to upgrade It to higher rates of performance and quality and raised the efficiency of the offered services provided so that they practically benefit each of the following categories: Jordanian university departments, employees, and the local community.

\subsection{Definition of Terms}

Comprehensive Quality Management: It is "an administrative philosophy based on customer satisfaction, and fulfilling his needs and expectations in present or in future" (Deming, 1980, 66).

It is known as the method by which the organization can continuously improve performance at all levels of work through the optimal use of the available human and material resources (Muslim, 2018).

Jordanian universities: They are "institutions established under a law of their own, and they have a legal personality with financial, administrative and scientific independence, and are supervised by the state. The period of study in them is not less than four years or equivalent, and at least the first university degree Bachelor's degree - is granted "(Ministry of Higher Education and Scientific Research, 2009).

International standards: It is "a set of specifications adopted by international quality organizations such as (International Organization for Standardization (ISO 9001-2000) and international quality standards, principles, elements and models applied in the United States of America, the European Union and Japan) (Al-Beshi, 2015, p. $8)$. 


\section{Theoretical Background}

\subsection{Quality Concept}

Quality is defined according to the International Organization for Standardization and Metrology (ISO 9000) as a measure of the extent of customers' needs and their stated and implicit requirements are met in addition to that it defined as a "degree that match the product to customer requirements (Crosby, 1980, 26).

\subsubsection{Quality in Islamic Civilization}

The Almighty said: "And you will see the mountains and think them solid, but they shall pass away as the passing away of the clouds. The work of Allah, Who perfected all things, verily, He is Well-Acquainted with what you do" (Surah An-naml, p. 88); and Prophet Mohammad, may God's peace and blessings be upon him, said "God loves if one of you does a job to master it," and this is an absolute saying in every work, product and service that must be mastered and brought out with the best acceptable results. The Islamic religion urges us not only to achieve quality but also to achieve the goal of the quality process, which is to master works and elevate them to the highest levels of performance that we wish (Al-Tety, 2010). Quality in Islamic thought means mastery in everything, which means achieving the required features in the product or service provided in a way that satisfies God Almighty through the Muslim's sensing the self-censorship, which means that the employee is monitoring himself by himself for fear of God Almighty (who knows the secret and concealed) and then please the owner of the work who pays the reward and all of that in order to gain the beneficiary customer and provide the product or service that he aspires to and benefit from, The Mustafa, May God's peace and blessings be upon him says: "God loves if one of you does a job to master it (Al-Huneidi, 2008).

According to (Majeed and Ziadat, 2015) perfection versus (quality) and there is another term that carries the same meaning and importance that is "charity" which means "giving above duty, and fulfilling the conditions and increasing, "God Almighty says in (Surah Al-Mulk, p. 2); "Who has created death and life that He may test you which of you is best in deed. And He is the All-Mighty, the Oft-Forgiving" which requires a Muslim to do charity in every work and every statement that a Muslim does and to do it in the best way possible, pursuant to what God Almighty says (Surah An-Nahl, p. 90) (Allah enjoins Al-Adl (i.e. justice and worshipping none but Allah Alone- Islamic Monotheism) and Al-Ihsan (i.e. to be patient in performing your duties to Allah)", therefore the method of comprehensive quality management is found in the teachings of our Islamic religion. In our noble Sharia, there are strong principles and concepts that call for a Muslim to perfect his work every day and in his works,and acts of worship so that God may be pleased with him and he is satisfied with himself, and others be satisfied with him, and Islam has been keen on quality in all the work that a Muslim does and the services $\mathrm{h}(\mathrm{e}$ provides to seek satisfaction, God is keen on the interests of Muslims, Al-Hadawi (2011) and this confirms his saying (Repentance Al-Taubah, p. 105): "Do deeds! Allah will see your deeds, and so will His Messenger, and the believers. And you will be brought back to the Knower of the unseen and the seen; Then He will inform you of wahat you used to do."

One of the principles of comprehensive quality that the Qur'an promoted is the principle of Shura, where Islam called for a commitment to consult with individuals and groups in making decisions and solving problems. And God mentioned in his book many verses that urge to consult the Shura, as in his speech to his Messenger in his saying "and consult them in the affairs" (Surah Al Imran: 159).In that verse, a clear reference to the Messenger of God is to set an example for the men of his state in adhering to the work of the Shura, and taking it as a basic principle of life; Because it produces positive results that directly affect the critical decisions that benefit people (Al-Saleh \& Al-Saremi, 2015).

Aishawi (2013) states that censorship, whether external or subjective, leads to ensuring implementation of the goals and standards set in accordance with Islamic legal standards, standards and controls, and that the Muslim has full responsibility for his actions in this world and the hereafter, and this appears through the Almighty saying in (Surah Al-Muddaththir, p. 38) "Every person is a pledge for what he has earned". And the principle of cooperation: Muslims are required to cooperate on all good and prevent all evil, the Exalted, the Majestic, says :( And cooperate with one another in virtue, righteousness and piety but do not help one another in sin and transgression (AlMaidah. P. 1). (It is well known that beneficial actions carried out in cooperation make the performance more quality and effective (Al-Qaisi, 2011).

\subsubsection{The Concept of Comprehensive Quality}

According to (Mossard, 1991, p. 28) comprehensive quality can be defined as the use of available resources to improve the services provided by the organization, and to assess the level by which the needs of customers in the present and future are satisfied, in the field of university education it is the total efforts exerted by workers in the 
educational field to raise the level of the educational product (the student), in a manner that is commensurate with the requirements of society, and what these efforts require from the application of a set of educational and pedagogical standards necessary to raise the level of the student through the concerted efforts of all workers in the field of education.

\subsubsection{The Concept of Comprehensive Quality Management}

Comprehensive Quality Management can be defined according to (Crosby, 1979, p. 20) as the systematic, structured way to ensure the activities planned in advance in the educational field it is defined as the degree to which learners are able to represent educational goals and apply them in behavior and work in any field, which is reflected in the systems and other sectors of society with consent and benefit.

\subsubsection{Comprehensive Quality Management in University Education:}

Researchers differed about the concept of comprehensive quality management in higher education, as it was defined as a philosophy that leads all organizational processes in the educational environment to achieve the satisfaction of students and their parents, also it is an administrative strategy It works on building an educational organization to serve students and is dedicated to their satisfaction through continuous improvement in the organization's effectiveness, efficiency and operations (Alzahrani, et. 2016; Amena, 2019).

\subsection{International Quality Standards}

Achieving the quality of administrative processes in institutions requires specifying the references (standard standards and models) that must be met in every process from planning and ending with monitoring and evaluation, and these models and standards help the administration in measuring its performance towards achieving comprehensive quality in the light of its standards, principles and elements (Sarhan, 2011).

\subsubsection{Edward Deming's Quality Model}

Perhaps one of Deming's most important contributions in the field of quality are: the necessity of the commitment of business organizations, and at all job levels, beginning with senior management, and even the executive levels in the organization, to apply the fourteen criteria of defining and publishing the goals and objectives of the organization, adopting a new philosophy of work, and not relying on total examination, and relying on the quality of the materials purchased, not the lower price, improving the production and service system continuously, paying attention to training, and finding Effective leadership, eliminating fear, activating teams, and avoiding hollow advice and slogans Avoid setting numerical goals for workers, support workers' pride in their work, and encourage learning and development ,Self, and make the appropriate change to drive the conversion (Jawda, 2012, p. 31).

\subsubsection{Armand Feigenbaum Model}

Fingum's philosophy focuses on several criteria that must be taken into account to raise the level of quality, including that quality becomes a management style, an ethical process, and that there should be a continuous development of quality, and quality and cost are both an integrated whole with no conflict between them, and making quality a wide-ranging process adopted by the institution (Al-Awad, 2012).

\subsubsection{Malcom Balderge Model}

The Balderge model includes several components (Al-Aythawi \& Al-Samarrai, 2011) they are:

1. Leadership and it represents: senior management, the system of leadership and organization, and the responsibility of society and citizenship.

2. Information and analysis, which includes: information management and comparison between them, analysis and use of academic achievement levels.

3. Action planning and strategic planning, which includes: strategic development and implementation of strategies.

4. Manpower development and management, which includes: assessment and planning of the workforce, the operating system of the teaching staff, and the professional satisfaction of the teaching staff.

5. Educational Administration, which includes: designing, supporting and delivery of educational system, and educational research, as well as the performance and satisfaction of universities 


\subsubsection{Kaoru Eshakkawa Model}

One of the basic criteria for quality control is that it is based on the customer's direction and it is the core of the administrative process, and it depends entirely on the active participation of workers, in addition to the use of data by statistical means to assist in the decision-making process (Al-Beshi, 2015).

\subsection{Applying Comprehensive Quality Management Standards in Jordanian Universities}

The Council for Accreditation of Higher Education Institutions was established in Jordan, Under the Higher Education and Scientific Research Law No. (4) of (2005), the ambition to improve the quality and quality of higher education has led to the transformation of the Council into an accreditation body independent of the Ministry of Higher Education. The Authority has established clear standards for both faculty, laboratory supervisors, buildings, academic facilities, classrooms, amphitheaters, specialized laboratories, workshops, libraries, playgrounds, health clinics, public facilities, utilities and educational means, and the development and adoption of instructions and bases for determining capacity and raising it, the adoption of academic programs, the axes of general accreditation of higher studies and the calculation of capacity (Ahmad \& Hussain, 2009).

The process of applying comprehensive quality management goes through five main stages as indicated by (Al-Tayiy, 2008):

First: The stage of convincing and management adoption of the philosophy of comprehensive quality management philosophy.

Second: The planning stage, in which detailed plans for implementation are established and the permanent structure and resources needed to implement the system are defined.

Third: The evaluation stage and it often begins with some important questions, which, in light of the answer, can create the appropriate base to start implementing comprehensive quality management.

Fourth: The implementation phase: in which the individuals who will be entrusted with the implementation process are selected and trained in the latest training methods related to comprehensive quality management.

Fifth: The stage of exchanging and disseminating experiences and at this stage, the experiences and successes that are achieved from the application of the comprehensive quality management system.

\section{Previous Studies}

Al-Harrahsha Study (2015) aimed to evaluate university performance in the light of comprehensive quality management from the viewpoint of administrative workers at Al Al-Bayt University. The study sample consisted of (122) individuals, and the study reached that the level of evaluation of university performance came with moderate rating.

Dudin (2014) conducted a study aimed at identifying practices related to application Comprehensive Quality Management in Higher Education Institutions in Jordan, the study sample consisted of (180) administrative academic employees who were chosen, by the stratified random method, and the results showed that there is no difference in the requirements for applying Comprehensive quality management in higher education institutions from the viewpoint of administrative academics with different gender variables and experience.

Bani Awad (2013) conducted a study aimed at identifying the possibility of applying comprehensive quality management in Jordanian universities and the obstacles that limit their application, and the proposed solutions, and the study community consisted of faculty members at Yarmouk University, Al-Bayt University, and Jerash University, and they numbered (664) And a random stratified sample was selected of them (416), and the results of the study showed that the degree of obstacles as a whole came high for the fields of technical and administrative obstacles.

Leng (2009) conducted a study that aimed to focus on the degree of application of comprehensive quality management standards in order to effect change in different educational situations in Singapore, as well as to know the views of the faculty about the impact of Edward Deming's fourteen principles In Quality Management, on faculty members use and integrate information and communication technology into the educational process, and the study sample included (70) faculty members were randomly selected in Singapore, and a questionnaire was developed for this purpose.The results of the study indicated that the degree of application of quality was high, and that the principles of comprehensive quality management, especially continuous training, positively affect the application of the faculty in Singapore in communication and information technology.

Cheung and Yipping (2009) study aimed to know the feasibility of applying the principles of comprehensive quality management in education in China from the viewpoint of Chinese teachers, the study sample consisted of 
(42) teachers distributed in five Chinese provinces, and the results of the study indicated that Chinese teachers see comprehensive quality management principles as helpful in enhancing the quality of education.

Gavriel and Romar (2007) also conducted a study that aimed at demonstrating how to implement comprehensive quality management in higher education, by identifying and analyzing the dual roles of students and teachers. The study reached to an understanding of the roles of the student and the teacher, and how to better apply the comprehensive quality in education. It also provided a way to enhance the evaluation process as a measure of the quality of education, and to provide measures that could strengthen students 'motivation to seek knowledge.

The following is the comment on the previous studies that were addressed in this study, as it was found that some studies have examined the criteria of comprehensive quality management in terms of the possibility and effectiveness of their application in universities and institutions of higher education in Jordan such as the study (Beni Awad, 2013) and the study (Al-Harrahsha, 2015 ), And some foreign studies such as (Cheung and Yipping, 2009) study conducted in China, and Gavriel and Romar (2007) study conducted in the United States of America, where these studies in their entirety dealt with concepts of comprehensive quality management, quality standards, applications and problems facing Implementation processes, where it came out with many results, the most important of which is the success of comprehensive quality management implementation largely depends on management and organizational culture prevailing in the organization.

The current study has benefited from previous studies in designing the study tool and enriching the theoretical framework, and distinguished from previous studies in that it revealed the degree of application of comprehensive quality management standards in Jordanian universities in the light of international standards within the areas of (vision, mission and goals, operations management, and continuous improvement, The satisfaction of the beneficiaries and the calendar )which, according to the researcher, had not been done by any of the previous studies.

\section{Methodology of the Study}

The descriptive approach is used to identify the degree of application of total quality management standards in Jordanian universities in the light of international standards.

\subsection{The Study Population and its Sample}

The study population consists of 437 heads of the academic departments in the public Jordanian universities (Ministry of Higher Education and Scientific Research, 2014). The stratified random sampling was used. The study sample consists of 216 heads of academic departments from Yarmouk University, Mutah University, and the University of Jordan, 171 of which responded to the questionnaire, i.e. (79\%) of the sampling units. Table (1) shows distribution of the final study sample according to (gender, years of experiences, specialization, and region) variables.

Table 1. Frequencies and percentages of the sampling units according to variables

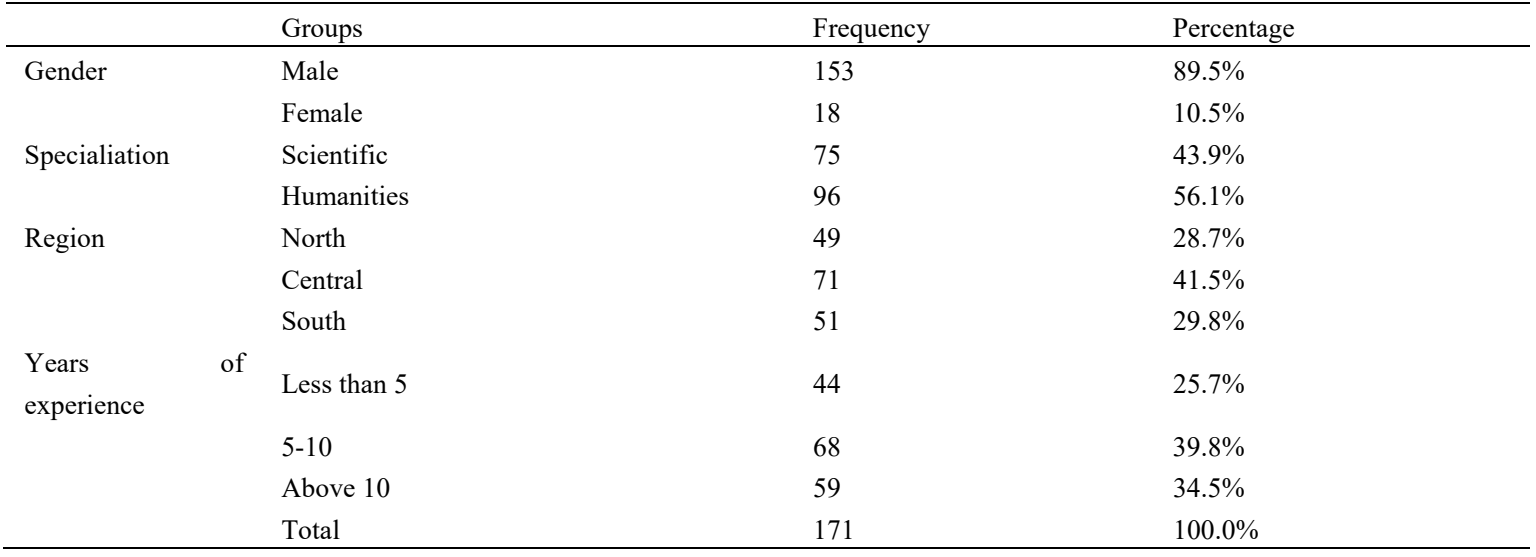

\subsection{The Study Tool}

Having reviewed the relevant literature, and the international standards that include the International Organization for Standardization (ISO 9001-2000) and international quality standards and models, a 
questionnaire was designed. The primary questionnaire consisted of (35) items divided into five areas: (Vision and Mission, Operations Management, Continuous Improvement, Client Satisfaction, Feedback).

The primary questionnaire was presented to (15) referees specialized in the field of educational management and quality in Jordanian universities. They were asked to determine the relevance of items to areas, as well as clarity and wording of such items to measure the degree of application of total quality management standards in Jordanian universities in the light of international standards. They were also requested to provide any suggestions, and suggest any items they deem necessary. Consequently, the adjustments suggested by the referees were made. Accordingly, the final questionnaire consisted of (45) items.

Reliability of the tool was verified using Test-Retest method. After two weeks, the tool was reapplied to a group, other than the study sample, consisting of 18 heads of academic departments. Then, Pearson correlation coefficient was calculated among their estimates both times.

\section{Results}

The arithmetic means, standard deviations, quadratic variance analysis, and dimensional comparisons, using Scheffe' Test, were used.

Question 1: "What is the degree of application of total quality management standards in the public Jordanian universities in the light of international standards from perspective of heads of academic departments?"

To answer this question, the arithmetic means and standard deviations of the degree of application of total quality management standards in the Jordanian universities from perspective of heads of academic departments were distracted, as shown in Table 2.

Table 2. Means and standard deviations of the degree of application of total quality management standards in the Jordanian universities from perspective of heads of academic departments (in descending order)

\begin{tabular}{|c|c|c|c|c|c|}
\hline Rank & Number & Area & Arithmetic mean & $\begin{array}{l}\text { Standard } \\
\text { deviation }\end{array}$ & Degree \\
\hline 1 & 1 & Vision, mission and objectives & 3.67 & .782 & Medium \\
\hline 2 & 4 & Client satisfaction & 3.56 & .808 & Medium \\
\hline 3 & 2 & Operations managment & 3.51 & .799 & Medium \\
\hline 4 & 3 & Constinious improvment & 3.48 & .789 & Medium \\
\hline \multirow[t]{2}{*}{5} & 5 & Evaluation & 3.37 & .870 & Medium \\
\hline & & Total & 3.51 & .760 & Medium \\
\hline
\end{tabular}

Table 2 shows that the arithmetic means range between (3.37-3.67) with a medium degree. The area of mission and vision ranks first with the highest arithmetic mean of (3.67), while the area of evaluation ranks last with an arithmetic mean of (3.37). The arithmetic mean of the tool as whole is (3.51).

Question 2: Are there statistically significant differences at the level of significance $(0.05=\alpha)$ in the degree of application of total quality management standards in the public Jordanian universities in light of international standards from the perspective of heads of academic departments according to gender years of experience, specialization, region variables?

To answer this question, the arithmetic means and standard deviations of the degree of application of total quality management standards in the Jordanian universities from perspective of heads of academic departments according to gender, years of experience, specialization, region variables, were distracted, as shown in Table 3.

Table 3. The arithmetic means and standard deviations of the degree of application of total quality management standards in the Jordanian universities from perspective of heads of academic departments according to gender, years of experience, specialization, region variable

\begin{tabular}{|c|c|c|c|c|c|c|c|c|}
\hline & Gender & & $\begin{array}{l}\text { Vision, } \\
\text { mission and } \\
\text { objectives }\end{array}$ & $\begin{array}{l}\text { Operations } \\
\text { managment }\end{array}$ & $\begin{array}{l}\text { Continious } \\
\text { improvment }\end{array}$ & $\begin{array}{l}\text { Client } \\
\text { statisfcation }\end{array}$ & Evaluation & $\begin{array}{l}\text { Total } \\
\text { degree }\end{array}$ \\
\hline \multirow[t]{2}{*}{ Gender } & Male & $\mathrm{m}$ & 3.66 & 3.52 & 3.49 & 3.56 & 3.39 & 3.52 \\
\hline & & $\mathrm{s}$ & .768 & .804 & .784 & .810 & .868 & .759 \\
\hline
\end{tabular}




\begin{tabular}{|c|c|c|c|c|c|c|c|c|}
\hline \multirow{5}{*}{ Specialization } & \multirow[t]{2}{*}{ Female } & $\mathrm{m}$ & 3.70 & 3.38 & 3.45 & 3.57 & 3.24 & 3.47 \\
\hline & & $\mathrm{s}$ & .914 & .767 & .854 & .817 & .904 & .791 \\
\hline & \multirow[t]{2}{*}{ Scientific } & $\mathrm{m}$ & 3.76 & 3.58 & 3.47 & 3.60 & 3.43 & 3.56 \\
\hline & & $\mathrm{s}$ & .791 & .856 & .793 & .833 & .876 & .774 \\
\hline & \multirow[t]{2}{*}{ Humanities } & $\mathrm{m}$ & 3.60 & 3.45 & 3.49 & 3.52 & 3.33 & 3.48 \\
\hline \multirow{3}{*}{ Region } & & $\mathrm{s}$ & .771 & .752 & .790 & .791 & .866 & .751 \\
\hline & \multirow[t]{2}{*}{ North } & $\mathrm{m}$ & 3.50 & 3.29 & 3.31 & 3.38 & 3.11 & 3.32 \\
\hline & & $\mathrm{s}$ & .727 & .763 & .742 & .767 & .808 & .693 \\
\hline \multirow{10}{*}{$\begin{array}{l}\text { Years } \\
\text { experience }\end{array}$} & \multirow[t]{2}{*}{ Central } & $\mathrm{m}$ & 3.60 & 3.35 & 3.28 & 3.41 & 3.15 & 3.35 \\
\hline & & $\mathrm{s}$ & .961 & .915 & .909 & .970 & .982 & .895 \\
\hline & \multirow{2}{*}{ South } & $\mathrm{m}$ & 3.93 & 3.93 & 3.93 & 3.93 & 3.94 & 3.93 \\
\hline & & $\mathrm{s}$ & .420 & .422 & .371 & .363 & .363 & .354 \\
\hline & \multirow[t]{2}{*}{ Less than 5} & $\mathrm{~m}$ & 3.90 & 3.81 & 3.81 & 3.85 & 3.76 & 3.82 \\
\hline & & $\mathrm{s}$ & .572 & .535 & .567 & .526 & .654 & .538 \\
\hline & \multirow[t]{2}{*}{$5-10$} & $\mathrm{~m}$ & 3.72 & 3.55 & 3.51 & 3.59 & 3.41 & 3.55 \\
\hline & & $\mathrm{s}$ & .723 & .791 & .823 & .810 & .800 & .734 \\
\hline & \multirow[t]{2}{*}{ Above 10} & M & 3.44 & 3.24 & 3.21 & 3.31 & 3.04 & 3.24 \\
\hline & & $\mathrm{S}$ & .920 & .889 & .806 & .908 & .965 & .840 \\
\hline
\end{tabular}

Notes. $\mathbf{M}=$ arithmetic mean $\mathbf{S}$ : standard deviation.

Table 3 shows an apparent variation in the arithmetic means and standard deviations due to the different variables of gender, years of experience, specialization, and region.

To demonstrate the significance of the statistical differences between the arithmetic means, multiple quadratic variance analysis was used for areas Table 4.

Table 4. Multiple quadratic variance analysis of the impact of gender, years of experience, specialization, and region on the degree of application of the total quality management in the Jordanian universities

\begin{tabular}{|c|c|c|c|c|c|c|}
\hline Source of variance & Areas & $\begin{array}{l}\text { Total } \\
\text { squares }\end{array}$ & $\begin{array}{l}\text { Degree of } \\
\text { freedom }\end{array}$ & $\begin{array}{l}\text { Mean } \\
\text { squares }\end{array}$ & F value & $\begin{array}{l}\text { Statistical } \\
\text { significance }\end{array}$ \\
\hline Gender & Vision, mission and objectives & .411 & 1 & .411 & .707 & .402 \\
\hline Hotlling $=0.19$ & Operations management & .050 & 1 & .050 & .089 & .766 \\
\hline \multirow[t]{3}{*}{$\mathrm{H}=.695$} & Continious improvment & .414 & 1 & .414 & .763 & .384 \\
\hline & Client satisfication & .625 & 1 & .625 & 1.045 & .308 \\
\hline & Evaluation & .261 & 1 & .261 & .419 & .518 \\
\hline Specialziation & Vision, mission and objectives & 1.034 & 1 & 1.034 & 1.778 & .184 \\
\hline Hotlling $=.049$ & Operations management & .738 & 1 & .738 & 1.302 & .256 \\
\hline \multirow[t]{3}{*}{$\mathrm{H}=.173$} & Continious improvment & .009 & 1 & .009 & .017 & .897 \\
\hline & Client satisfication & .428 & 1 & .428 & .716 & .399 \\
\hline & Evaluation & .740 & 1 & .740 & 1.188 & .277 \\
\hline Region & Vision, mission and objectives & 1.986 & 2 & .993 & 1.708 & .184 \\
\hline Welx $=.850$ & Operations management & 6.472 & 2 & 3.236 & 5.710 & .004 \\
\hline \multirow[t]{3}{*}{$\mathrm{H}=.003$} & Continious improvment & 7.798 & 2 & 3.899 & 7.186 & .001 \\
\hline & Client satisfication & 5.467 & 2 & 2.734 & 4.572 & .012 \\
\hline & Evaluation & 12.758 & 2 & 6.379 & 10.239 & .000 \\
\hline Years of experience & Vision, mission and objectives & 1.738 & 2 & .869 & 1.495 & .227 \\
\hline Welx $=.974$ & Vision, mission and objectives & 1.606 & 2 & .803 & 1.417 & .245 \\
\hline \multirow[t]{2}{*}{$\mathrm{H}=.931$} & Operations management & 1.625 & 2 & .812 & 1.497 & .227 \\
\hline & Continious improvment & 1.515 & 2 & .758 & 1.267 & .284 \\
\hline
\end{tabular}




\begin{tabular}{|c|c|c|c|c|c|c|}
\hline & Client satisfication & 2.084 & 2 & 1.042 & 1.673 & .191 \\
\hline \multirow[t]{5}{*}{ Error } & Vision, mission and objectives & 2403.704 & 171 & & & \\
\hline & Operations management & 2212.755 & 171 & & & \\
\hline & Continious improvment & 2181.740 & 171 & & & \\
\hline & Client satisfication & 2275.222 & 171 & & & \\
\hline & Evaluation & 2072.860 & 171 & & & \\
\hline \multirow[t]{5}{*}{ Total } & Vision, mission and objectives & 103.889 & 170 & & & \\
\hline & Operations management & 108.494 & 170 & & & \\
\hline & Continious improvment & 105.847 & 170 & & & \\
\hline & Client satisfication & 111.073 & 170 & & & \\
\hline & Evaluation & 128.605 & 170 & & & \\
\hline
\end{tabular}

Table 4 shows that there are no statistically significant differences $(\alpha=0.05)$ attributable to the impact of (gender, specialization, years of experience) in all areas, and that are statistically significant differences $(5=0.05)$ attributable to the impact of the region on all areas save the area of vision, mission and objectives. To demonstrate differences that are statistically significant between the arithmetic means, the dimensional comparisons were used according to Scheffe Test, as shown in Table 5.

Table 5. Dimensional comparisons of impact of region on the degree of application of total quality management standards in Jordanian universities by Scheffe Test

\begin{tabular}{|c|c|c|c|c|c|}
\hline & & Arithmetic mean & North & Central & South \\
\hline \multirow{3}{*}{$\begin{array}{l}\text { Operations } \\
\text { management }\end{array}$} & North & 3.29 & & & \\
\hline & Central & 3.35 & .06 & & \\
\hline & South & 3.93 & $.64 *$ & $.58^{*}$ & \\
\hline \multirow{3}{*}{$\begin{array}{l}\text { Continious } \\
\text { improvement }\end{array}$} & North & 3.31 & & & \\
\hline & Central & 3.28 & .02 & & \\
\hline & South & 3.93 & $.63^{*}$ & $.65^{*}$ & \\
\hline \multirow[t]{3}{*}{ Client satisfaction } & North & 3.38 & & & \\
\hline & Central & 3.41 & .02 & & \\
\hline & South & 3.93 & $.55^{*}$ & $.53 *$ & \\
\hline \multirow[t]{3}{*}{ Evaluation } & North & 3.11 & & & \\
\hline & Central & 3.15 & .03 & & \\
\hline & South & 3.94 & $.83^{*}$ & $.79^{*}$ & \\
\hline \multirow[t]{3}{*}{ Total degree } & North & 3.32 & & & \\
\hline & Central & 3.35 & .04 & & \\
\hline & South & 3.93 & $.62 *$ & $.58^{*}$ & \\
\hline
\end{tabular}

Note. $\left({ }^{*}\right)$ significance level $(0.05=\alpha)$.

Table 5 shows that there are statistically significant differences $(5=0.05)$ between the south on the one hand both the north and the central on the other hand, where differences are in favor of the south in all areas.

\section{Discussion}

The findings of the study show that the total arithmetic mean for the areas of the degree of application of the total quality management standards in Jordanian universities in the light of international standards from the perspective of heads of academic departments is medium, i.e. (3.51). The researcher argues that this is due to the 
recent application of the total quality management standards in light of international standards in Jordanian universities in general and the public Jordanian universities in particular. These universities need a new organizational culture that includes understanding and perception of new changes intended to be applied in Jordanian public universities so that they guide human behavior of all workers. This is also attributed to the use of the principle of centralization in taking decisions which leads to sticking to the routine. The findings of this study agree with (Al-Harrahsha, 2015) whose findings show that the university performance evaluation level is medium.

As for the gender variable, this study shows that there are no statistically significant differences at the level $(\alpha=$ 0.05 ) attributed to the impact of gender on the areas of total quality management standards namely vision, mission and goals, operations management, continuous improvement, client satisfaction and evaluation. Accordingly, the gender variable does not play a role in applying total quality management standards in Jordanian universities in the light of international standards. Hence, the level of application of total quality management standards by heads of academic departments, whether male or female, in Jordanian public universities does not differ. This may be due to the fact that these standards are adopted by international organizations for standardization and have no impact on the responses of heads of departments, male or female, and that heads of departments in universities are entrusted with equal tasks and duties under the university law without regard to the gender variable.

With regard to the years of experience variable, the findings show that there are no statistically significant differences at the significance level $(0.05=\alpha)$ in the application of total quality management standards in Jordanian universities in the light of international standards attributable to the years of experience variable in all areas. This indicates that the years of experience variable play no role in the application of the total quality management standards. In other words, the level of application of quality management by heads of academic departments does not differ according to the different years of experience. This may be due to the fact that the degree of application of total quality management standards has nothing to do with the department heads' experience, competence and values, ambition for improvement and the degree of satisfaction with the processes of application of quality management standards.

As to the specialization variable, the findings show that there are no statistically significant differences at the significance level $(=0.05=\alpha)$ in the degree of application of total quality management standards in Jordanian universities in light of international standards attributed to the specialization variable in all fields. This means that the application of total quality management standards is not limited to a specific specialization concerning the responses of heads of humanities or scientific departments and is not related to the degree of qualification for the application of these standards. This is due to the fact that the total quality management standards in Jordanian public universities are subject to the same administrative regulations.

With respect to the region variable, the findings show that there are statistically significant differences at the significance level $(=0.05=\alpha)$ attributed to the impact of the region on the areas of operations management, continuous improvement, client satisfaction, and evaluation. However, there are no statistically significant differences in the area of vision, mission and objectives. In order to show the statistically significant differences between the arithmetic means, the dimensional comparisons were used by Scheffe' Test. The findings show that there are statistically significant differences $(5=0.05)$ between the southern region on the one hand and the northern and central regions on the other hand. The differences are in favor of the southern region in all areas. The researcher attributes this to the modernity of these universities, which contributes to achieving the goals.

\section{Recommendations}

In light of the findings of the study, it is recommended that:

-This degree is increased by holding training courses and field workshops to activate the total quality management standards, all university employees, administrators and academics are trained to ensure that they are fully familiar with the principles of total quality management.

-The universities adopt a clear and specific development strategy to implement the concepts and standards of total quality management, in order to develop their performance and improve the level of service quality in them.

-The universities' infrastructure is supported with the equipment that helps to improve the level of quality, the culture of total quality is disseminated in universities, and the total quality's technical methods and implementation stages are familiarized.

\section{References}

Ahmad, A., \& Hussain, M. (2009). Ensuring the quality of higher education institutions in light of the standards 
of international Accredition bodies. Cairo: The world of books.

Aishawi, A. (2013). Total quality management theoretical, applied and organizational foundations in the commodity and service institutions. Jordan: Alhamed House.

Alzahrani, K., Bashayer, A., \& Azrilah, A. (2016). Total quality management in Saudi higher education information, system department faculty of computing \& information. International Journal of Computer applications, 4(135). https://10.5120/ijca2016908245

Amena, D. (2019). Educational quality standards between the imperative of adoption and the obstacles to implementation in the Algerian School. Scientific Horizons Magazine, 1(18) (in Arabic).

Awwad, W. (2012). The basics of total quality management. Kingdom of Saudi Arabia: Future House.

Aythawi, A., \& Samurai, A. (2011). The reality of applying the quality assurance of education in private universities in the light of comprehensive quality standards and requirements. The Arab International Conference on Quality Assurance in Higher Education, Zarqa University, Jordan, 10-12 May (in Arabic).

Bani Awad, M. (2013). Implementing Total quality in Jordanian universities, obstacles and solutions. Jerash University, Jordan (in Arabic).

Beshi, S. (2015). Evaluating the effectiveness of schools for gifted students in Jordan in light of international quality standards. Balqa Applied University, Jordan (in Arabic).

Cheung, C., \& Yipping, W. (2008). The Feasibility of implementing total quality management principles in Chinese Education: Chinese Educators. Perspectives Educational Planning, 2(17), 10-22.

Crosby, P. (1979). Quality is free: The art of quality certain. New York: McGraw- Hill Book Company.

Crosby, P. (1980). Quality is free: The art of making quality certain. U.S.A.: New York, Mentor Executive Library.

Deming, E. (1980). Transformation of western style of management. Interfaces, 3(15), 6-17. https://doi.org/10.1016/S0169-7161(88)07003-8

Dudin, A. (2014). The role of Applying total quality management requirements in higher education institutions in Jordan from the Viewpoint of academic Administrators. The fourth Arab conference for quality assurance in higher education, Zarqa University, 1-3 April (in Arabic).

Gavriel, M., \& Romar, E. (2007). The difficulty in implementing total quality management in higher education instruction: The duality of instructor/ student roles. Quality Assurance in Education, 14(4), 22-53. https://doi.org/10.1108/09684880610703938

Ghamdi, A. (2009). The importance of comprehensive quality standards for Islamic education teachers in the primary stage from the point of view of specialists. Umm Alqura University, Kingdom of Saudi Arabia (in Arabic).

Haddawi, J. (2011). Modern management from an Islamic perspective. Alyaman: Standardization of Publications.

Harrahsha, M. (2015). Evaluating university performance in the light of total quality management from the viewpoint of administrative staff at Al-Bayt University. The Seventh conference on quality and accreditation in education, White House: Morocco, 7-8 December (in Arabic).

Huneidi, J. (2008). The principles of comprehensive quality in Islam and some of its applications in Islamic education. Cairo: University Publishing House.

Jawda, M. (2012). Total quality management: Concepts and applications. Amman: Wael Publishing House.

Leng, E. (2009). Total quality management principles that influence the integration of information and communications technology into the classroom. Asia-pacific education researcher, 18(2), 317-327. https://doi.org/10.3860/taper.v18i2.1332

Majeed, S., \& Zyadat, M. (2008). Quality in Education, Applied Studies. Jordan: Serenity House for Publication and Distribution.

Majeed, S., \& Zyadat, M. (2015). Total quality management: Industry and trade applications. Jordan: Serenity House for Publication and Distribution.

Ministry of Higher Education and Scientific Research. (2009). Jordanian University Law and its Amendments. Law, (20). 
Mossard, G. (1991). A TQM technical skills framework. Journal of management Science \& Policy Analysis, 1(8), 11-34.

Muslim, R. (2018). The Degree of application of the principles of total quality management in government basic schools in Aqaba, Jordan, from the teachers 'point of view Middle East University, Jordan (in Arabic).

Qaisi, H. (2011). The philosophy of quality management in education and higher education (Methods and Practices). Jordan: Curicula House for Publication and Distribution.

Saleh, S., \& Saremi, K. (2015). Total quality: Origin- development- method. Jordan: House of Thought.

Sarhan, F. (2011). Total Quality Management Modern Global Administrative Trends. Cairo: Sharif Mas Library for Publishing and Distribution.

Shehata, S. (2012). The Foundations of assessing learner performance and measuring the effectiveness of the educational institution. International Journal of Educational Research, 1(31), 27-30 (in Arabic).

Tayiy, Y., Abadi, M., \& Abadi, H. (2008). Total Quality Management in Higher Education. Jordan: Paper House for Publication and Distribution.

Tety, K. (2010). Quality management and industry: Administrative, technical, and commercial concepts in quality. Jordan: Alhamed House for Publication and Distribution.

\section{Copyrights}

Copyright for this article is retained by the author(s), with first publication rights granted to the journal.

This is an open-access article distributed under the terms and conditions of the Creative Commons Attribution license (http://creativecommons.org/licenses/by/4.0/). 